\title{
Perioperatív vérfelhasználás: közös kockázat, közös feladatok, közös felelösség
}

\author{
Babik Barna dr. ${ }^{1}$ - Fazakas János dr. ${ }^{2}$ - Matusovits Andrea dr. ${ }^{3}$ \\ Gál János dr. ${ }^{4}$ - Fülesdi Béla dr. ${ }^{5}$ \\ ${ }^{1}$ Szegedi Tudományegyetem, Általános Orvostudományi Kar, Aneszteziológiai és Intenzív Terápiás Intézet, \\ Szeged \\ ${ }^{2}$ Semmelweis Egyetem, Általános Orvostudományi Kar, Transzplantációs és Sebészeti Klinika, Budapest \\ ${ }^{3}$ Országos Vérellátó Szolgálat, Budapest \\ ${ }^{4}$ Semmelweis Egyetem, Általános Orvostudományi Kar, Aneszteziológiai és Intenzív Terápiás Klinika, Budapest \\ ${ }^{5}$ Debreceni Egyetem, Általános Orvostudományi Kar, Aneszteziológiai és Intenzív Terápiás Klinika, Debrecen
}

\begin{abstract}
Az emberi vörösvértest-koncentrátum és thrombocytaszuszpenzió labilis készítmények, ezért biológiai és gazdasági okokból nem szereplői a nemzetközi (gyógyszer)piacnak, így nem is pótolhatók külső forrásból. A humán allogén vörösvértest- és thrombocytakészítményeket a fentiek alapján a közös nemzeti vagyon részének kell tekintenünk. Újratermelésük, optimális felhasználásuk rendszerszintű gondolkodást, az esetleges hiányukból fakadó közös kockázatok közös feladatokat és közös felelősséget jelenítenek meg a betegellátás gyakorló résztvevői és irányítói számára egyaránt. A transzfúzióra került vörösvérsejt-koncentrátum mennyisége a fejlett egészségügyi rendszerrel rendelkező országokban az utóbbi években csökken. A változások mögött kezdetben a megengedő (liberális) és megszorító (restriktív) transzfúziós határérték (trigger) fogalmának és gyakorlatának terjedése állt, később megjelent a perioperatív vérfelhasználás komplex, átgondolt rendszere, a Patient Blood Management, illetve Nemzeti Véradó és Vérmentő Program, és paradigmaváltás jelentkezett az életveszélyes perioperatív vérzések ellátásában is. A biztonságos és elégséges vérellátás ezzel párhuzamos, erőteljes kihívása, hogy világszerte csökken a véradási hajlandóság. Az emberi vörösvértest-koncentrátum és thrombocytaszuszpenzió felhasználásának észszerúsítése elengedhetetlen Magyarországon. Egészséggazdasági intézkedésként segíthetné a vérmegtakarítást, ha az életveszélyes vérzések ellátása során a haemostasis helyreállítására használt allogén készítményekre, illetve stabil faktorkoncentrátumokra fordítható, jelenleg mereven elkülönített pénzügyi források az intézmények számára átjárhatóvá válnának. A perioperatív felhasználást klinikai eszközökkel csökkentené a Nemzeti Véradó és Vérmentő Program széles körű terjesztése, mely összetett és összehangolt oktatási, interdiszciplináris szervező és logisztikai, irányítói munkát kíván.
\end{abstract}

Orv Hetil. 2020; 161(37): 1545-1553.

Kulcsszavak: vörösvértest-koncentrátum, Patient Blood Management, életveszélyes perioperatív vérzések ellátása, faktorkészítmények, haemostasisresuscitatio

\section{Perioperative Patient Blood Management: common risk, common tasks, common responsibility}

Human red blood cell concentrate and platelet suspension are unstable preparations, therefore, they are not part of the international pharmaceutical market for biological and economic reasons. Consequently, they cannot be replaced by external sources. Human allogeneic erythrocyte and platelet preparations should therefore be considered as part of the common national wealth. The amount of transfused red blood cell concentrate has been declining in countries with advanced health systems in recent years. The changes were initially driven by the spread of the concept and practice of liberal and restrictive transfusion triggers. A complex, thoughtful system of perioperative blood utilization, the Patient Blood Management has later emerged, and a paradigm shift in the delivery of life-threatening perioperative bleeding has developed. At the same time, clinical practitioners are facing a new challenge of reducing willingness to donate blood worldwide. The rationalization of the use of human red blood cell concentrate and platelet suspension is essential in Hungary. As a health care measure, the currently rigidly earmarked financial resources available for allogeneic preparations and stable factor concentrates for the treatment of life-threatening haemorrhages need to be 
changed to be interoperable. The perioperative blood use could additionally be reduced by the widespread dissemination of the Patient Blood Management requiring complex coordinated educational interdisciplinary and logistical work.

Keywords: red blood cell concentrate, Patient Blood Management, management of life-threatening perioperative bleeding, factor concentrates, haemostasis resustitation

Babik B, Fazakas J, Matusovits A, Gál J, Fülesdi B. [Perioperative Patient Blood Management: common risk, common tasks, common responsibility]. Orv Hetil. 2020; 161(37): 1545-1553.

(Beérkezett: 2020. május 20.; elfogadva: 2020. június 20.)

\section{Rövidítések}

EMMI = Emberi Erőforrások Minisztériuma; HBCS $=$ homogén betegségcsoportok; $\mathrm{MT}=$ masszív transzfúzió; $\mathrm{MV}=$ masszív vérzés; $\mathrm{OVSZ}=$ Országos Vérellátó Szolgálat; $\mathrm{PBM}=$ (Patient Blood Management) hazai adaptációja a Nemzeti Véradó és Vérmentő Program; WHO = (World Health Organization) Egészségügyi Világszervezet

\section{A vér mint gyógyszer: nemzeti kincs}

A humán allogén vörösvértest-koncentrátum és thrombocytaszuszpenzió transzfúziója adott esetben mással nem helyettesíthető, azonnal szükséges, életmentő beavatkozásként a medicina elengedhetetlen, integrált részévé vált. Az emberi vér és az ebból készített preparátumok fontosságát és mindenkori gyors elérhetőségét egészségügyi és társadalmi, más aspektusból szakmai és jogi szempontok alapján lehetetlen túlbecsülni.

$\mathrm{Az}$ emberi vörösvértest-koncentrátum és thrombocytaszuszpenzió labilis készítmény, következésképpen ezek a készítmények biológiai és gazdasági okokból nem szereplői a nemzetközi (gyógyszer)piacnak, nem pótolhatók külső forrásból. Mindenkori elérhetőségükről, észszerü tartalékok biztosításáról folyamatosan magunknak kell gondoskodnunk.

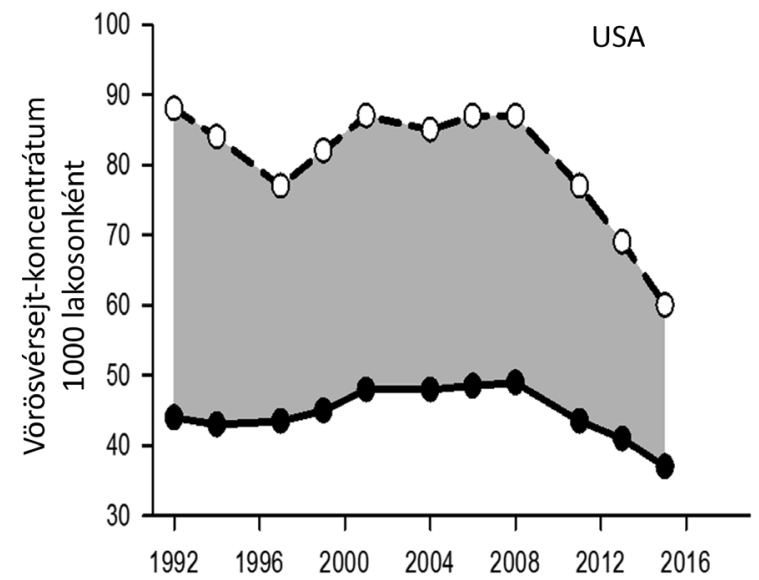

A humán allogén vörösvértest- és thrombocytakészítményeket a fentiek alapján a közös nemzeti vagyon részének kell tekintenünk. Újratermelésük, optimális felhasználásuk rendszerszintû́ gondolkodást, az esetleges hiányukból fakadó közös kockázatok közös feladatokat és közös felelősséget jelenítenek meg a betegellátás gyakorló résztvevői és irányítói számára egyaránt.

\section{A vér- és vérkészítmény-gazdálkodás: tendenciák a nemzetközi és a hazai gyakorlatban}

\section{A transzfúzióra került vörösvérsejt- koncentrátum mennyisége sok, átgondolt egészséggazdasági elvek mentén és magas anyagi ráforditással müködö, fejlett egészségügyi rendszerrel rendelkezö országban csökken, Magyarországon változatlan}

- Az Amerikai Egyesült Államokban az évenként transzfúzióra került vörösvérsejt-koncentrátum mennyisége az 1990-es évek közepétől növekedő tendenciát mutatott, ez az irány 2009-ben markánsan megfordult.

Magyarország

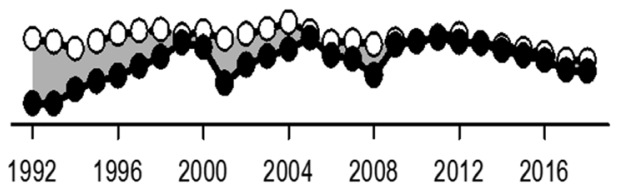


A csökkenés 2009 óta napjainkig folyamatos, és üteme erőteljesebb, mint az azt megelőző évtizedben a növekedésé volt. Az USA-ban jelenleg a transzfundált vörösvérsejt-koncentrátum 1000 lakosra vetített, évenkénti mennyisége így már kevesebb, mint 1997 ben volt (1. ábra, bal panel) [1-3]. A vérfelhasználás a perioperatív területen csökkent a legnagyobb mértékben, 41,5\%-kal [4], pedig az elmúlt 20 évben a sebészeti beavatkozások mennyiségi expanziója, spektrumuk bővülése természetszerúleg folytatódott. A betegek egyre nagyobb hányada idős, különféle társbetegségek és lehetséges perioperatív szövődmények magas arányával. A transzfúzióra került vörösvérsejtkoncentrátum évenkénti mennyisége hasonló csökkenést mutatott az elmúlt évtizedben Ausztráliában, az Egyesült Királyságban [5] és Hollandiában [6].

- A nemzetközi trenddel szemben Magyarországon az 1000 lakosra vetített, transzfúzióra került vörösvérsejt-koncentrátum évenkénti mennyisége az elmúlt két évtizedben nem mutatott lényeges változást (1. ábra, jobb panel).

\section{Az allogén transzfúziós beavatkozások csökkenéséhez vezetō körülmények}

Változások a transzfúzió indikációja területén: megjelent a megengedő (liberális) és a megszorító (restriktív) transzfúziós határérték (trigger) fogalma

- A transzfúzió indikációját fél évszázad során meghatározó, a hemoglobin- és a hematokritértékekre vonatkoztatott, klasszikus „10/30”-as szabályt [7] és az annak megfelelő homogén gyakorlatot betegbiztonsági és financiális szempontok feszítették szét. Először egy amerikai állásfoglalás kérdőjelezte meg a 100 g/l hemoglobin egyedüli, transzfúziót indikáló szerepét, és felhívta a figyelmet, hogy az enyhe, illetve közepes anaemia nem növeli a perioperatív morbiditást [8]. A 2000-es években sorra jelentek meg a magas anyagi ráfordítással finanszírozott, fejlett egészségügyi rendszerrel rendelkező országokban nemzeti, majd nemzetközi irányelvek a mérsékelt anaemiát megengedő, megszorító (restriktív) transzfúziós gyakorlatról [9]. A megszorító transzfúziós gyakorlat a beteg fiziológiás tartalékainak jobb kihasználásával járult hozzá a globális vérmegtakarításhoz, és egyúttal ezen törekvések fontosságára irányította a szakmai figyelmet. A változások fontos szerepet töltöttek be a vérmegtakarításban, ugyanakkor megosztó hatásúak is voltak, amit a nemzetközi irodalomban megjelenő nagyszámú közlemény és az esetenként a betegágy melletti döntéshozatalba legyưrüző polémia mutat. Nem véletlenül. A megengedő és a megszorító transzfúziós határérték elve és gyakorlata ugyanolyan uniformist kölcsönöz a döntéseknek, mint a régi, „10/30"-as szabály, csak alacsonyabb perioperatív oxigenizációs tartalékokkal. Ezt az uniformist próbálta lebontani betegcsoport-specifikus transzfúziós érték megjelölé- sével egy szisztémás, áttekintő vizsgálat és metaanalízis, mely szerint a 65 évnél idősebb betegek esetében a megengedő transzfúziós stratégia előnyösebb a 30 és a 90 napos mortalitás szempontjából [10]. Hasonlóan magasabb hemoglobin tartása szükséges akut coronaria szindrómában [11] vagy a szívsebészetben [12]. Teoretikusan a betegspecifikus optimális hemoglobinérték becslésén alapuló transzfúziós indikáció a legkedvezőbb, az alap- és társbetegségeknek, a beavatkozás jellegének, az aktuális állapotnak, illetve ezek klinikai és laboratóriumi mutatóinak a figyelembevételével. Az individuális mérlegelés azonban nem könnyú, és még várat magára, hogy a betegspecifikus hemoglobin-határérték meghatározásának szempontjai általánossá váljanak, és irányelvben megjelenjenek.

- Magyarországon a perioperatív ellátásban részt vevő szakmák heterogén irányelvei és eltérő gyakorlata miatt - az erre irányuló szakmai törekvések ellenére - a restriktrív transzfúziós stratégia nem tudott általános elvként és jellemző perioperatív gyakorlatként megjelenni a betegellátásban, így hozzájárulása az allogén transzfúziós beavatkozások csökkenéséhez elhanyagolható.

\section{A perioperatív vérfelhasználás komplex, átgondolt rendszere: Patient Blood Management, illetve Nemzeti Véradó és Vérmentő Program}

- Hozzávetőlegesen egy időben a megengedő és a megszorító transzfúziós határérték fogalmának bevezetésével, Ausztráliából indult a Patient Blood Management (PBM) néven összefoglalt új kezdeményezés [13]. Ez a program a megszorító transzfúziós stratégiát összetettebb módon kezeli, és perioperatív kontextusba helyezi. A PBM az individuális betegellátást, a betegbiztonságot és a vérmegtakarítást jelölte meg alapvető céljaiként, és az ezek eléréséhez szükséges feladatokat három csoportba („pillérbe”) rendezte $[14,15]$. Az első pillér a beteg saját vörösvérsejtmassza-mennyiségének optimalizálása elektív mútétek előtt („a beteg termeljen magának vért a mütét előtt"), amennyiben az lehetséges. Az anaemia az egyik leggyakoribb kóros elváltozásként az emberek 25\%-ában fordul elő, 1,8-2 milliárd embert érint [16]. Ez az arány a sebészeti beavatkozásra kerülő betegek körében még magasabb, akár a 75\%-ot is elérheti [6]. Az anaemiás elváltozások egyharmada vashiányos, és így megfelelő szubsztitúciós kezeléssel elektív mútétek előtt korrigálható. A PBM második pillérét azok a feladatok alkotják, melyek révén a diagnosztikus, intervenciós és sebészi vérzések csökkenthetők. Első az egyenlők között jelentőséggel idetartozik a megfelelő sebészi szövetkezelés és vérzéscsillapítás, valamint aneszteziológiai hozzájárulásként a betegágy melletti teszteken, faktorkoncentrátumokon és koagulációs algoritmusokon alapuló gyors és hatékony vérzéscsillapítás. Nagyobb várható vérvesztés esetén 'cell saver' technika javasolt. Világos indikációkkal kell 
választani invazív monitorozási technikát az egyre többféle, modern technológiával rendelkezésre álló, nem invazív módszerek birtokában. A perioperatív időszakban csak a szükséges laborvizsgálatokat kérjük, terápiás következményekkel járó kérdések felállításával. Fontos a lehető legrövidebb intravénás vagy intraartériás hosszabbítók alkalmazása. Előnyös, ha az intézményi laboratórium előtérbe helyezi a kisebb vérvolumennel dolgozó gyermekvizsgálati technikákat. A jelentéktelennek tűnő vérveszteségek összeadódva jelentőssé válnak: egy szívsebészeti tanulmány szerint a perioperatív időszakban átlagosan 115 , vérvétellel járó laborvizsgálat történt, $454 \mathrm{ml}$ kumulatív medián vérveszteséggel [17]. A második pillér feladatait frappánsan összefoglalva: tartsuk szem előtt, hogy a lehetőségekhez mérten a „betegnek joga van megtartani a saját vérét" [15]. A PBM harmadik pillére a restriktív transzfúziós stratégiát integrálja rendszerbe, amennyiben a keringés, a légzés, a szedálás és az egyéb vitális funkciók optimalizálásával az anaemiával szembeni betegspecifikus toleranciát kívánja növelni. A PBM evidenciaalapú, multidiszciplináris, a WHO által elfogadott és támogatott betegellátó tevékenységi forma [18]. Mivel önmagukban jól ismert, sok szakmát érintő preventív és terápiás elemeket tartalmaz és strukturál újra az individuális ellátás, a betegbiztonság és a vérmegtakarítás érdekében, „múködési egysége" a kórház [15]. Ma Németországban mintegy 100 intézmény csatlakozott a programhoz. A PBM-elvek és -gyakorlat betartásával 17\%-os további vérmegtakarítást értek el [15, 19], és csökkent a transzfúziós ráta ortopédiai beavatkozások során 24,5\%-ról 10,1\%-ra, szívsebészeti mütétek alkalmával 60\%-ról 25\%-ra [20].

- Magyarországon a PBM elterjedésére irányuló első lépések a közelmúltban megtörténtek. Nemzeti Véradó és Vérmentő Program néven megkezdődtek a megbeszélések a hazai bevezetésról az egészségügyi kormányzat és az aneszteziológia és intenzív terápia szakma vezetői között. Jelenleg a feladatok felmérése zajlik, a program hatása várhatóan pár éven belül válik érezhetôvé.

\section{Paradigmaváltás az életveszélyes perioperatív} vérzések ellátásában: élvonal és középmezőny

- Az életveszélyes periprocedurális masszív vérzésekről (MV-k) akkor beszélünk, ha a teljes vértérfogat 24 óra alatti, a vértérfogat felének 3 óra alatti elvesztése vagy rövidebb távon $150 \mathrm{ml} /$ perc, esetleg 20 percen át történő, 1,5 ml/perc/kg vérzés áll fenn. A súlyos állapot sokszor gyógyítható alapbetegségben szenvedő betegek, esetleg traumás fiatalemberek, szülő nők és családjuk számára jeleníti meg a beteg elvesztésének valós és közeli veszélyét. Ellátásuk korábban, a 2000-es években a transzfuziológia elvének és gyakorlatának megfelelő „vérkomponens-terápia” három alapvető termékének: a vörösvértest-koncentrátum- nak, a friss fagyasztott plazmának és a thrombocytaszuszpenziónak a lehetôség szerint minél korábbi, nagy mennyiségű, szimultán, masszív transzfúzióján (MT; a teljes vértérfogat 24 óra alatti kicserélése, pótlása) alapult $[21,22]$. Az életveszélyes periprocedurális vérzések kezelésében a 2010-es években jelentős változások jelentek meg a jelentős anyagi erők és átgondolt egészséggazdasági elvek szerint múködő, fejlett egészségügyi rendszerrel rendelkező országok többségében [23-30]. Előtérbe került a stabil alvadásifaktor-készítmények használata, mert „a fibrinogén plazmaszintjét a friss fagyasztott plazma csak fenntartani képes, ezt emelni csak koncentrátummal lehet” [31, 32]. A nagy töménységű, standardizált, immunizációt nem okozó, melegítést nem igénylő, így azonnal használható faktorkészítmények alkalmazása szakmai szempontból a vérkomponens-terápia egyenes továbbgondolása, igy plazmakomponens-terápiának tekinthetó, technikai oldalról pedig gyártástechnológiai és logisztikai fejlesztésekre épülō elórelépés. Az új irányelvekben nagy hangsúlyt kapott továbbá a betegágy melletti viszkoelasztikus haemostaticus tesztek alkalmazása a coagulopathia gyors karakterizálása és a haemostaticus terápia vezetése, tehát a terápia egyénre szabása céljából [27-30]. A paradigmaváltás eredményeképpen a MV és a MT addig szoros, obligát összekapcsolása szétválaszthatóvá vált a terhességi haemostasisadaptáció „természettől ellesett” élettani mechanizmusának analógiájára [33]. Ma már egyértelmú, hogy megfelelő preemptív lépésekkel jelentős vérmegtakarítás érhető el ebben a betegcsoportban, hiszen a korai célvezérelt haemostasisresuscitatio egyben a további vérzés és a következményes transzfúzió szekunder prevenciójának is tekintheto" [31, 34-41].

A korai célvezérelt haemostasisresuscitatio direkt költséghatékonyságát vizsgáló tanulmányok szerint szívsebészeti beavatkozások során a betegágy melletti tesztek és faktorkoncentrátumok használata nem volt drágább [32], sőt 6,5\%-os direkt megtakarítás volt elérhető [42], mely aortadissectio miatti mütéteknél 40\%-ra nőtt [43], míg más, összetett szívmütéteknél a költségek megfeleződtek [44]. Általános sebészeti betegek körében 11,5\%-os [45], súlyos nőgyógyászati vérzéseknél [46] és traumás betegeknél [47] jelentős költségmegtakarítás jelentkezett. Ezek az eredmények ebben a formában Magyarországra nem extrapolálhatók, mert a hivatkozott német, olasz, osztrák, egyesült államokbeli, ausztrál, holland közlemények a jelenlegi magyar vérkészítményárszintnél magasabb árakkal számoltak. A vérkészítmények anyagi vonzatai azonban hazánkban is növekedhetnek a nem túl távoli jövőben. A korai célvezérelt haemostasisresuscitatio indirekt költséghatékonyságát is vizsgáló tanulmányok magukban foglalják az intenzív osztályos és kórházi tartózkodás költségeit, valamint a szövődmények kezeléséből fakadó kiadásokat is. Ilyen típusú elemzésekből összetettségüknél adódóan még kevés áll ren- 
delkezésre, de azok kisebb mortalitásról, rövidebb lélegeztetési időről, kevesebb dialízist igénylő veseelégtelenségről számolnak be [48], és a kisebb menynyiségű transzfúzióból következő egészségnyereség várhatóan hasonlóan kedvező eredményekhez vezet.

- Magyarországon az életveszélyes periprocedurális vérzések ellátásában jelentős elmozdulás tapasztalható a korai célvezérelt haemostasisresuscitatio alkalmazásának mind szélesebb körű terjedésében. A fejlődésben fontos szerep jut a nemzetközi ajánlásokkal koherens vonatkozó, EMMI egészségügyi szakmai magyar irányelvnek [49], a faktorkoncentrátumok terjedésének, a betegágy melletti viszkoelasztikus monitorozás megismerésének és alkalmazásának, a graduális és szervezett, interdiszciplináris posztgraduális képzéseknek és múhelygyakorlatoknak. A további előrelépésnek azonban jelentős akadályát képezi, hogy az ellátás financiális struktúrája jelenleg nincs teljesen összhangban azokkal a szakmai kívánalmakkal, melyeket a nemzetközi irányelvek és a Magyar Aneszteziológiai és Intenzív Terápiás Társaság Szakmai Kollégiuma által jóváhagyott, multidiszciplináris EMMI egészségügyi szakmai irányelv, valamint a képzési és a szakvizsga-követelmények tükröznek, és a maguk teljességében be nem tartott elvek különféle kártérítési célzatú eljárások során mindenki számára hozzáférhető hivatkozási lehetőséget is teremthetnek. Jelenleg a financiális ellátórendszer korlátlanul liberális az allogén vérkészítmény felhasználásával és az erre fordított intézményi/intézeti ráfordításokkal, mert a transzfúziós terápia per se olyan erőteljes szakmai, társadalmi, szociális, erkölcsi tartalmat és értéket hordoz, hogy annak el nem végzését anyagi okokra hivatkozva senki nem vállalhatja. Ez tükröződik is a vérkészítményekhez párosított inkasszói jogban. A finanszírozási szisztéma ugyanakkor általánosságban restriktív a MV és MT szövődményeinek - mint az elhúzódó lélegeztetés, keringéstámogatás, vesepótló eljárások, szepszis, sebgyógyulási zavarok - többnyire intenzív osztályos kezelésével kapcsolatban, mert az ezek HBCS-kódjai által közvetített anyagi eróforrások az intenzív osztályok és a kórházvezetés általános megítélése szerint a gyógyítás szükségleteit nem kellóen fedezik. Végezetül, a financiális források eröteljesen restriktivek a MV és MT korai célvezérelt, személyre szabott csökkentésére, tehát a további vérzés és transzfúzió, valamint szövődményei szekunder prevenciójára, mert a súlyosan vérző beteg ellátására a magyar és a nemzetközi ajánlások által javasolt új szakmai és eszköztartalmakat a korábban kidolgozott HBCS még nem foglalja magában. Jelenleg tehát sokat költünk, de nem észszerüen!

- Összefoglalva, a korai célvezérelt haemostasisresuscitatiónak az európai és a magyar szakmai ajánlásokban egyaránt szereplő, a beteg egyénnek egészségnyereséget, az országnak vérmegtakarítást eredményező, diagnosztikus és terápiás, taktikai és stratégiai újításai
Magyarországon csak nehézkesen és részben valósíthatók meg. Az előrelépés fó akadályát a szakmai újításokat természetszerúleg még nem ismerő, a változásokat megelözốn kialakitott egészséggazdasági pénzügyi struktúra képezi. Jelenleg a rendelkezésre álló humánés anyagi erőforrásokból elismerésre méltóan nagy hányadot fordítunk az életveszélyes periprocedurális vérzések ellátására, de nem elég racionálisan.

\section{Csökken a véradási hajlandóság}

- A véradási hajlandóság az utóbbi években világszerte csökken, annak ellenére, hogy átgondolt és erőteljes lépések történtek és történnek a donáció növelésére, például a donortoborzásnak az új nemzedékekre adaptált, új típusú kommunikációjával, a donoregészségfelügyelet erôsítésével vagy a donorkészítmény-recipiens útvonal lehető legészszerúbb szervezésével [1-3, 50]. Az Egyesült Államokban a csökkenés 2008-ban indult el, és tendenciája eröteljesebb, mint a transzfúzió csökkenésében megfigyelhető trend, pedig a véradói korhatárt 2008-ban két évvel csökkentették [1]. A jelenlegi folyamatok egy évtized múlva az USA-ban vérellátási nehézségekhez vezethetnek. Az 1000 lakosra vetített vérdonációsvértranszfúziós görbék jelzik azonban azt is, hogy az Egyesült Államokban a donáció 60-80\%-a tartósan és trendszerüen meghaladja a közvetlen transzfúziós igényeket, ami jelentős biztonsági tartalékot és profitképes gyógyszergyártási alapot is jelent (1. ábra, bal panel, és 2. ábra).

- Magyarországon az 1000 lakosra számított vérdonációs és transzfúziós adatok ezzel szemben azonnali lépések ultimátumszerü megtételére figyelmeztetnek (1. ábra, jobb panel és 2. ábra). Az utóbbi 10 évben

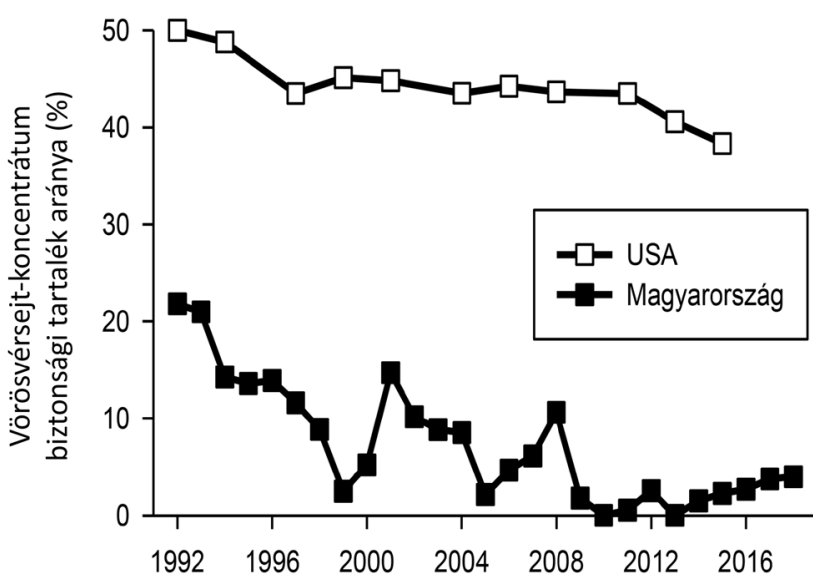

2. ábra

Az 1000 lakosra számított, biztonsági tartalékot jelentő vörösvérsejt-koncentrátum aránya a donációhoz képest az Amerikai Egyesült Államokban (üres négyzet) és Magyarországon (teli négyzet) az elmúlt két évtizedben. Magyarországon ez 2010ben és 2013-ban 1\%-nál kevesebb volt. Közel félmillió egység gyújtött, illetve transzfúzióra kiadott vérforgalom mellett 110 , illetve 123 egység képezte a „tartalékot”! 
donáció során gyưjtött vér mennyisége országos szinten, tartósan csak pár százalékkal haladja meg a transzfúzióra kiadott vörösvérsejt-koncentrátum mennyiségét! Tartalék szinte nincs, a két görbe nyári vagy járványidőszakban kereszteződhet, időszakos vérkészítményhiányt okozva. Mivel az Országos Vérellátó Szolgálat (OVSZ) évtizedek óta rendkívül odaadó munkával, maximális erőkifejtéssel dolgozik a mindenkori biztonságos vértartalékok kiépítéséért is, nyilvánvaló, hogy a megoldást a felhasználás optimalizálásában kell keresni.

\section{Lehetséges (szüikséges) általános feladatok a hazai perioperatív vérellátási egyensúly fenntartására}

A vérkészítmény-ellátás fenyegető egyensúlyvesztését mindenképpen meg kell előzni, mert az beláthatatlan, rendkívül súlyos szakmai, gazdasági és társadalmi feszültségeket generálna! A biztonsági tartalékok kiépítése a véradói hajlandóság jelenleg nehezen befolyásolható, világszerte jelentkező csökkenése miatt csak a perioperatív felhasználás optimalizálása, egyértelmúen fogalmazva: csökkentése útján látszik megvalósíthatónak [4]. A transzfúziós igény érezhető, globális csökkentése Magyarországon két, egymással párhuzamos úton látszik megvalósíthatónak.

1. A perioperatív vérfelhasználás csökkentésének financiális módja Magyarországon annak a jelenleg érvényben lévő, betegellátási finanszírozási gyakorlatnak a megváltoztatása, mely az életveszélyes vérzések haemostasisresuscitatiójára korlátlanul támogatja az allogén vérkészítmények használatát, de nem ad kellő finanszírozási hátteret a hatékony és bizonyítékokon alapuló, nemzetközi és magyar irányelvek által támogatott, faktorkoncentrátumokra és betegágy melletti haemostaticus tesztekre építő technikáknak. Ez a változtatás nélkülözhetetlen, mert a jelenleg finanszírozott lehetőség nem takarékoskodik az emberi vérrel, nem elég hatékony az egyes betegek potenciális egészségnyereségének maximalizálásában, és nem költséghatékony, hiszen a vérkészítmény-alapú haemostasisresuscitatio - tehát a masszív transzfúzió - sok és jelentős humán-, illetve anyagi erőforrást igénylő, további szövődményt is generál. A változtatás legfontosabb eleme, hogy a Finanszírozási és Kódkarbantartási Bizottság a 180/2010. (V. 13.), Eljárás befogadás szabályozásáról szóló Kormányrendelet alapján az életveszélyes perioperatív és peripartum vérzések kezelésére az utóbbi 10 évben megjelent nemzetközi, valamint az Egészségügyi Szakmai Kollégium által jóváhagyott, multidiszciplináris EMMI egészségügyi szakmai irányelvben szereplő ajánlások mentén a korai célvezérelt haemostasisresuscitatio új szakmai és eszköztartalmát a megfelelő eljárásrendnek megfelelően befogadja.
- A befogadott eljárás megjelenhet a 15/2018. (VI. 28.) EMMI rendeletnek megfelelően, kiegészítő HBCS formájában az életveszélyes vérzések ellátása során fellépő diagnosztikus és terápiás lépések fedezetére az inhalációs nitrogén-monoxidvagy a terápiás hypothermia kezelés mintájára.

- Kiegészíthető egészséggazdasági intézkedésként segíthetné az életveszélyes vérzések ellátását, ha a haemostasis helyreállítására használt allogén készítményekre, illetve stabil faktorkoncentrátumokra fordítható, jelenleg mereven elkülönített pénzügyi forrásokat az intézmények számára átjárhatóvá tennék. Optimális használatukról szakmai meggondolások alapján határozzon a haemostasisresuscitatióban kiképzett orvos, és életmentő döntéseit ne például az osztály aktuális, hónap végi gyógyszerrendelő potenciálja szabja meg. Ahogy vért természetesen tud adni bármikor, faktorkoncentrátum is lehessen elérhető folyamatosan. A véralvadás helyreállítására fordított labilis allogén és stabil faktorkoncentrátumok finanszírozástechnikai egyesítése mellett szól szakmailag, hogy egymást helyettesítő készítményekről van szó, pénzügyileg pedig az, hogy az egyikre fordított kiadás a másikon megtakarításhoz vezet. Technikailag ez úgy oldható meg, hogy a kórházi gyógyszertárakban, a gyógyszergazdálkodási programokban a transzfúziót helyettesítő stabil faktorkészítményeket a „vérkészítmények” kategóriába sorolják, és nem a "gyógyszer” csoportba, ami jobban meg is felel a klinikai alkalmazásuknak.

2. A perioperatív felhasználás csökkentésének klinikai útja Magyarországon a Nemzeti Véradó és Vérmentő Program széles körü terjesztése a hazai klinikai gyakorlatban. A program sikeres térnyerése érdekében nélkülözhetetlen a szakmai ismeretek és érdeklődés "remodellingje" a perioperatív medicinában vagy áttételesen ezzel kapcsolatban dolgozó orvosok számára. A megvalósítás érdekében elengedhetetlen továbbá egy nagyvonalú stratégiai elképzeléseket és aprólékos taktikai kidolgozottságot egyaránt magában foglaló egészségügyi kormányzati irányítói feladatvállalás. A program sikeréhez fontos még egy, a transzfúziós forgalmat követő, ezen keresztül a további teendőket, korrekciókat kijelölő pontos és gyors logisztikai rendszer igénybevétele.

A vértakarékosság mindkét útjának megvalósításához szükséges gyakorlati feladatok több ponton kapcsolódnak egymáshoz, közös halmazukat tartalmi és hatásköri szempontok alapján négy csoportra oszthatjuk.

1. Oktatási feladatok

- A Nemzeti Véradó és Vérmentő Programról szükséges mindenki számára könnyen érthető, magyar nyelvű, interdiszciplináris EMMI egészségügyi szakmai irányelvet készíteni, mely segítséget nyújtana a program végrehajtásában, különösen a bevezető időszakban. 
- Kívánatos, hogy a Nemzeti Véradó és Vérmentő Program rendszeresen megjelenjen perioperatív ellátást végző szakmai kongresszusokon, és keltsék fel, illetve tartsák ébren az érdeklődést a vértakarékosság elve és gyakorlata iránt.

- A posztgraduális, interdiszciplináris, interaktív, témaorientált kurzusok fontos szerepet játszanak a program széles körü megértésében és elfogadásában, a hallgatóság téma iránti elkötelezettségének kialakításában. A megbeszéléseket és előadásokat a Nemzeti Véradó és Vérmentő Program országos és intézményi irányítói, szervezői, végrehajtói szintjeinek megfelelően különböző célokkal és súlypontokkal kell felépíteni. Az első szint egyeztető megbeszéléseket foglal magában az egészségügyi ellátórendszer vezetésével. A második szint egynapos képzést ajánlana a kórházi vezetők számára, a program átfogó ismertetésével, különös tekintettel az irányítás és az ellenőrzés kérdéseire. Harmadik szintként önálló formában egyesíti az irányítói (második) és a végrehajtói szakmai (harmadik) tanfolyam tematikáját a Nemzeti Véradó és Vérmentő Program kórházigazgatók által kijelölt koordinátorai részére tartandó kétnapos tanfolyam, hiszen számukra a logisztikai és a klinikai ismeretek egyaránt fontosnak. A negyedik szint feladata egynapos posztgraduális képzések tartása a perioperatín medicinában dolgozó gyakorló orvosok részére, ezért a tanfolyam a negyedik szintnél jelzett szakmai kérdésekre fókuszál. Az ötödik szintet a tervek szerint egynapos képzés jelenti a perioperatív medicinában dolgozó asszisztensek, nővérek részére; a tematika pontos kialakítása az első év tapasztalatai alapján fog megtörténni.

- Az első tanfolyamokra a programban irányító szereppel rendelkező, vezető beosztásban dolgozó kollégák kapnának meghívást. A részükről kialakult elfogadottság a biztosítéka a kórház múködését átszövő vértakarékos új eljárások kivitelezésének és általánossá válásának.

2. A Nemzeti Véradó és Vérmentő Program interdiszciplináris jellegéhez kapcsolódó feladatok

A program fontos eleme az elektív mütétekre kerülő betegek esetleges anaemiájának felismerése és kezelése, ezért elengedhetetlen a háziorvosok és a belgyógyászok bevonása a klasszikus perioperatív klinikai környezetet meghatározó szereplők körébe. Természetesen a transzfuziológia, hematológia képviselőinek hozzájárulása is nélkülözhetetlen a Nemzeti Véradó és Vérmentő Program múködéséhez. Az OVSZ vagy a Magyar Kórházszövetség szervezeti partnerként várhatóan igen fontos résztvevője lesz a konzultációknak.

3. A Nemzeti Véradó és Vérmentő Program transzfúziós adatbázisának kialakítása

A transzfúzióra kiadott és a ténylegesen transzfúzióra került vérmennyiség pontos regisztrálásával az OVSZ precíz, gyors adatbázist tud kiépíteni, mely képes válasszal szolgálni a program globális és lokális sikereire, esetleg elmaradásaira. Az adatbázis így lehetőséget ad a pozitív vagy negatív visszajelzésekre, melyek a hoszszú távú múködés alapfeltételei.

4. A Nemzeti Véradó és Vérmentő Program államigazgatási jogszabályozási környezetének kialakítására történó javaslatok

- Az egészségügyi kormányzat az életveszélyes periprocedurális vérzések megfelelő ellátásához szükséges financiális struktúra mai szakmai standardokhoz alakításával alapjaiban képes javítani ezen betegek ellátását. A változtatásokhoz az előbbiekben részletezett javaslatainkkal kívántunk hozzájárulni.

- A kórházak „vértakarékos üzemmódra” való átállítása nem lehet sikeres anélkül, hogy az egészségügyi kormányzat az államigazgatási jogszabályozási súlyát felhasználva a kórházigazgatókat felkéri/kijelöli az általuk irányított intézményben a Nemzeti Véradó és Vérmentő Program céljai és feladatai végrehajtásának ellenőrzésére, valamint az általuk vezetett intézményben a Nemzeti Véradó és Vérmentő Program koordinátori személyének kijelölésére. A koordinátor felel a gyakorlati végrehajtásért, és a kórházigazgatónak tartozik beszámolni az eredményekről.

Anyagi támogatás: A szerzők a kézirat elkészítéséért anyagi támogatásban nem részesültek.

Szerzői munkamegosztás: A szerzők közösen végezték az irodalomkutatást, és vettek részt az egyes fejezetek előkészítésében és a kézirat megírásában. A cikk végleges változatát valamennyi szerző elolvasta és jóváhagyta.

Érdekeltségek: A szerzőknek nincsenek érdekeltségeik.

\section{Irodalom}

[1] Ellingson KD, Sapiano MR, Haass KA, et al. Continued decline in blood collection and transfusion in the United States - 2015. Transfusion 2017; 57(Suppl 2): 1588-1598.

[2] Whitaker B, Rajbhandary S, Kleinman S, et al. Trends in United States blood collection and transfusion: results from the 2013 AABB Blood Collection, Utilization, and Patient Blood Management Survey. Transfusion 2016; 56: 2173-2183. [Correction: Transfusion 2016; 56: 3149.]

[3] Chung KW, Basavaraju SV, Mu Y, et al. Declining blood collection and utilization in the United States. Transfusion 2016;56: 2184-2192.

[4] Sapiano MR, Savinkina AA, Ellingson KD, et al. Supplemental findings from the National Blood Collection and Utilization Surveys, 2013 and 2015. Transfusion 2017; 57(Suppl 2): 15991624.

[5] Bielby L, Moss RL. Patient blood management and the impor tance of the transfusion practitioner role to embed this into practice. Transfus Med. 2018; 28: 98-106.

[6] Shander A, Van Aken H, Colomina MJ, et al. Patient blood man agement in Europe. Br J Anaesth. 2012; 109: 55-68. 
[7] Adams RC, Lundy JS. Anesthesia in cases of poor risk: some suggestions for decreasing risk. Surg Gynecol Obstet. 1942; 74: $1011-1019$

[8] Consensus conference. Perioperative red blood cell transfusion. JAMA 1988; 260: 2700-2703.

[9] American Society of Anesthesiologists Task Force on Perioperative Blood Transfusion and Adjuvant Therapies. Practice guidelines for perioperative blood transfusion and adjuvant therapies: an updated report by the American Society of Anesthesiologists Task Force on Perioperative Blood Transfusion and Adjuvant Therapies. Anesthesiology 2006; 105: 198-208.

[10] Simon GI, Craswell A, Thom O, et al. Outcomes of restrictive versus liberal transfusion strategies in older adults from nine randomised controlled trials: a systematic review and meta-analysis. Lancet Haematol. 2017; 4: e465-e474.

[11] Hebert PC, Yetisir E, Martin C, et al. Is a low transfusion threshold safe in critically ill patients with cardiovascular diseases? Crit Care Med. 2001; 29: 227-234.

[12] Hajjar LA, Vincent JL, Galas FR, et al. Transfusion requirements after cardiac surgery: the TRACS randomized controlled trial. JAMA 2010; 304: 1559-1567.

[13] Isbister JP. Perioperative blood conservation strategies: weighing the medical evidence - II. Can J Anaesth. 2008; 55: 248-250.

[14] Farmer SL, Towler SC, Leahy MF, et al. Drivers for change: Western Australia Patient Blood Management Program (WA PBMP), World Health Assembly (WHA) and Advisory Committee on Blood Safety and Availability (ACBSA). Best Pract Res Clin Anaesthesiol. 2013; 27: 43-58.

[15] Zacharowski K, Spahn DR. Patient blood management equals patient safety. Best Pract Res Clin Anaesthesiol. 2016; 30: 159169

[16] Kassebaum NJ, Jasrasaria R, Naghavi M, et al. A systematic analysis of global anemia burden from 1990 to 2010. Blood 2014; 123: 615-624.

[17] Koch CG, Reineks EZ, Tang AS, et al. Contemporary bloodletting in cardiac surgical care. Ann Thorac Surg. 2015; 99: 779784 .

[18] World Health Organization. Availability, safety and quality of blood products. WHO 63/20/REC/1. 2010 March 25.

[19] Meybohm P, Herrmann E, Steinbicker AU, et al. Patient blood management is associated with a substantial reduction of red blood cell utilization and safe for patient's outcome: a prospective, multicenter cohort study with a noninferiority design. Ann Surg. 2016; 264: 203-211.

[20] Hare GM, Freedman J, David Mazer C. Review article: risks of anemia and related management strategies: can perioperative blood management improve patient safety? Can J Anaesth. 2013; 60: 168-175.

[21] Teixeira PG, Inaba K, Shulman I, et al. Impact of plasma transfusion in massively transfused trauma patients. J Trauma 2009; 66: 693-697.

[22] Holcomb JB, Wade CE, Michalek JE, et al. Increased plasma and platelet to red blood cell ratios improves outcome in 466 massively transfused civilian trauma patients. Ann Surg. 2008; 248: 447-458. [Correction: Ann Surg. 2011; 253: 392.]

[23] Spahn DR, Rossaint R. Coagulopathy and blood component transfusion in trauma. Br J Anaesth. 2005; 95: 130-139.

[24] Spahn DR, Cerny V, Coats TJ, et al. Management of bleeding following major trauma: a European guideline. Crit Care 2007; 11: R17.

[25] Rossaint R, Bouillon B, Cerny V, et al. Management of bleeding following major trauma: an updated European guideline. Crit Care 2010; 14: R52.

[26] Spahn DR, Bouillon B, Cerny V, et al. Management of bleeding and coagulopathy following major trauma: an updated European guideline. Crit Care 2013; 17: R76.
[27] Rossaint R, Bouillon B, Cerny V, et al. The European guideline on management of major bleeding and coagulopathy following trauma: fourth edition. Crit Care 2016; 20: 100.

[28] Kozek-Langenecker SA, Afshari A, Albaladejo P, et al. Management of severe perioperative bleeding: guidelines from the European Society of Anaesthesiology. Eur J Anaesthesiol. 2013; 30: 270-382. [Correction: Eur J Anaesthesiol. 2014; 31: 247.]

[29] Kozek-Langenecker SA, Ahmed AB, Afshari A, et al. Management of severe perioperative bleeding: guidelines from the European Society of Anaesthesiology: first update 2016. Eur J Anaesthesiol. 2017; 34: 332-395.

[30] Spahn DR, Bouillon B, Cerny V, et al. The European guideline on management of major bleeding and coagulopathy following trauma: fifth edition. Crit Care 2019; 23: 98.

[31] Brohi K, Eaglestone S. Traumatic coagulopathy and massive transfusion: improving outcomes and saving blood. NIHR Journals Library, Southampton (UK), 2017.

[32] Trevisan D, Zavatti L, Gabbieri D, et al. Point-of-care-based protocol with first-line therapy with coagulation factor concentrates is associated with decrease allogenic blood transfusion and costs in cardiovascular surgery: an Italian single-center experience. Minerva Anestesiol. 2016; 82: 1077-1088.

[33] Babik B. Hemostasis in pregnancy: a natural model of hemostasis resuscitation in patients with massive perioperative blood loss. [A véralvadási rendszer adaptációja terhességben: a hemosztázisreszuszcitáció természetes modellje masszív vérzésben.] Anaesthesiol Intenziv Ther. 2017; 47(2): 9-23. [Hungarian]

[34] Solomon C, Collis RE, Collins PW. Haemostatic monitoring during postpartum haemorrhage and implications for management. Br J Anaesth. 2012; 109: 851-863.

[35] Fahrendorff M, Oliveri RS, Johansson PI. The use of viscoelastic haemostatic assays in goal-directing treatment with allogeneic blood products - A systematic review and meta-analysis. Scand J Trauma Resusc Emerg Med. 2017; 25: 39.

[36] Wikkelsø A, Wetterslev J, Møller AM, et al. Thromboelastography (TEG) or rotational thromboelastometry (ROTEM) to monitor haemostatic treatment in bleeding patients: a systematic review with meta-analysis and trial sequential analysis. Anaesthesia 2017; 72: 519-531.

[37] Görlinger K, Fries D, Dirkmann D, et al. Reduction of fresh frozen plasma requirements by perioperative point-of-care coagulation management with early calculated goal-directed therapy. Transfus Med Hemother. 2012; 39: 104-113.

[38] Bolliger D, Tanaka KA. Point-of-care coagulation testing in cardiac surgery. Semin Thromb Hemost. 2017; 43: 386-396.

[39] Tang M, Fenger-Eriksen C, Wierup P, et al. Rational and timely haemostatic interventions following cardiac surgery - coagulation factor concentrates or blood bank products. Thromb Res. 2017; 154: 73-79.

[40] Wikkelsø A, Lunde J, Johansen M, et al. Fibrinogen concentrate in bleeding patients. Cochrane Database Syst Rev. 2013; 2013: CD008864.

[41] Naik BI, Pajewski TN, Bogdonoff DI, et al. Rotational thromboelastometry-guided blood product management in major spine surgery. J Neurosurg Spine 2015; 23: 239-249.

[42] Görlinger K, Dirkmann D, Hanke AA, et al. First-line therapy with coagulation factor concentrates combined with point-ofcare coagulation testing is associated with decreased allogeneic blood transfusion in cardiovascular surgery: a retrospective, single-center cohort study. Anesthesiology 2011; 115: 11791191.

[43] Hanke AA, Herold U, Dirkmann D, et al. Thromboelastometry based early goal-directed coagulation management reduces blood transfusion requirements, adverse events, and costs in acute type A aortic dissection: a pilot study. Transfus Med Hemother. 2012; 39: 121-128.

[44] Weber CF, Görlinger K, Meininger D, et al. Point-of-care testing: a prospective, randomized clinical trial of efficacy in coagu- 
lopathic cardiac surgery patients. Anesthesiology 2012; 117: 531-547.

[45] Smart L, Mumtaz K, Scharpf D, et al. Rotational thromboelastometry or conventional coagulation tests in liver transplantation: comparing blood loss, transfusions, and cost. Ann Hepatol. 2017; 16: 916-923.

[46] Snegovskikh D, Souza D, Walton Z, et al. Point-of-care viscoelastic testing improves the outcome of pregnancies complicated by severe postpartum hemorrhage. J Clin Anesth. 2018; 44: 50-56. [Correction: J Clin Anesth. 2018; 48: 8.]

[47] Whiting P, AI M, Westwood M, et al. Viscoelastic point-of-care testing to assist with the diagnosis, management and monitoring of haemostasis: a systematic review and cost-effectiveness analysis. Health Technol Assess. 2017; 19(58): 1-228.

[48] LaPar DJ, Crosby IK, Ailawadi G, et al. Blood product conservation is associated with improved outcomes and reduced costs after cardiac surgery. J Thorac Cardiovasc Surg. 2013; 145: 796804.

[49] Babik B, Blaskó Gy, Fazakas J, et al. Management of life-threatening perioperative haemorrhages. [Az életveszélyes perioperatív vérzések ellátása. A Magyar Aneszteziológiai és Intenzív Terápiás Társaság szakmai irányelve, 2013.] Aneszteziol Int Ter. 2013; 43: 113-143.] [Hungarian]

[50] Williamson LM, Devine DV. Challenges in the management of the blood supply. Lancet 2013; 381: 1866-1875.

(Babik Barna dr., Szeged, Semmelweis u. 6., 6720 e-mail: babikbarna@gmail.com)

\section{„Virtutis spolia cum videt, gaudet labor." (Az erény jutalmának láttán elégtételt nyer a fáradozás.)}

A cikk a Creative Commons Attribution 4.0 International License (https://creativecommons.org/licenses/by/4.0/) feltételei szerint publikált Open Access közlemény, melynek szellemében a cikk bármilyen médiumban szabadon felhasználható, megosztható és újraközölhető, feltéve, hogy az eredeti szerző és a közlés helye, illetve a CC License linkje és az esetlegesen végrehajtott módositások feltüntetésre kerülnek. (SID_1) 